\title{
The Evolution of United Nations Peacekeeping
}

Does multilateralism deserve moral suspicion? It is a well-put question, worth facing prior to our inquiry into peacekeeping. Some of the classical conditions of peacekeeping will be newly explicable; the classical limits to peacekeeping fit these moral concerns.

Traditionally, multilateralism has been challenged as a road to lassitude, inaction and self-defeat. The suggestion here is different. Professor Fernando Tesón has argued that multilateralism may fall prey to the moral short-sightedness of a purely self-regarding decision. Indeed, in international law circles, an enthusiasm for multilateralism sometimes brings a suspension of judgment. Even international lawyers who admit the deep interweaving of law and morality, drift towards a "multilateral positivism"-the presumption that if a decision is reached multilaterally, it can't be wrong. The Security Council, in this view, becomes a lawmaking institution; its actions create new norms eo ipso. The Security Council is its own law and sets its own principles. The ordinary inquiry appropriate to the intervention of one country into another country's affairs, a skepticism or burden of persuasion for unilateral intervention, turns to credulity if the action is multilateral.

In unilateral intervention, even upon the avowal of humanitarian or pro-democratic ends, we check to see whether a national actor is serving its own self-interest, including domestic political interests advanced by foreign action. We worry about lack of transparency in decisionmaking, the bluntness of the instruments, and the claims and rights of the target. Multilateral enthusiasms have been quite different. When the Cold War ended, there was a celebratory feeling; the United Nations had become unstuck after eons in frozen ice. The Security Council lost its stalemate and a carnival feeling set in-we really ought to cherish the Council for what it is doing and worry about the fine points later. In the work of some observers, there has been a beguiling invitation to defer critical judgment, enjoying the glow. This is a doubtful move because of politics, lack of transparency, and the value of autonomy.

The United Nations is a deeply political place. Members consider national self-interest. To a realist, Security Council action can be explained as the resolution of political vectors. Each country calculates its

* Ruth Wedgwood is Professor of Law at Yale Law School, and Senior Fellow and Director of the Project on International Organizations and Law at the Council on Foreign Relations.

28 CORNELl INT'L L.J. 631 (1995) 
national self-interest, and the interests of allied cooperative states, while speaking a universalist vocabulary. As a parlor sport, reverse-engineer the votes, figuring out who, what and why; you can often point to something else going on at the time. China's restoration to most-favored-nation status could have something to do with China's abstention in vital Security Council votes. Partialities may cancel each other out; a multilateral decision may coincide with the impartial view of an "ideal observer." But multilateral decisions can be political and self-serving rather than principled. As a check, we should ask each time whether a recommended action can be generalized, or whether it would be worrisome writ large. Our assay must continue to pay attention to the incidental harm force can work upon civilians, including enemy civilians, even where the Security Council is the actor. We must worry about the danger of faint-heartedness as well. As in Bosnia, a promise of protection can be destructive where real force is not available to back up the proffer.

Transparency is also lacking in multilateral decisionmaking. The Security Council often acts behind closed doors. Some General Assembly members feel aggrieved at their exclusion from the Council's deliberations. This year, troop-donating countries were allowed to have special consultations with Council members over peacekeeping mandates and the use of their troops. But a member of the General Assembly cannot waltz into the Security Council and watch all debates. There are many executive sessions. The Council is rather like the U.S. Senate in the late 18th century-an often opaque body delivering often opaque results-rather than the open structure we associate with a modern national parliament. Lacking transparency, a political Security Council and even General Assembly may not deserve any special deference beyond the perfection of the particular decisions.

Autonomy is the third concern. Although the U.N. Charter states that enforcement decisions taken by the Security Council fall outside the reserve of domestic jurisdiction of national states, political autonomy and local action remain valuable. Just as the European Union values the return of crucial decisions to the local level, as "subsidiarity," so we should value a global subsidiarity. A community must take responsibility for its own course and fate. The U.N. cannot function as deus ex machina. Our concern about the practice of colonial governance, that it may lead to passivity and political infantilism, should extend to multilateral colonialism as well. Colonialism was often benign in its purposes, but substituted another country's will and judgment for that of the local community, and retarded political maturation.

These concerns about politics, transparency, and autonomy help to account for the lingering orthodoxy of peacekeeping doctrine. Classical peacekeeping has demanded minimum force, party consent, and neutrality. These doctrinal tenets, as we shall see, flank and avoid foundational questions about multilateral decisionmaking. American bewilderment at European reticence in peacekeeping may follow from not understanding 
these worries about how multilateral institutions might be misused. Foundationalism can be avoided if little is at stake.

Minimal use of force is the first tenet of classical peacekeeping. Though peacekeepers wear military uniforms, the enterprise is closer to pacifism and the ethos of non-violence than to war-fighting or active police. The Lester Pearson/Dag Hammarskjöld account of peacekeeping, in the wake of the Suez crisis, was Nordic Minimalism. This sensibility eschews force wherever possible and rejects the instrumental use of arms to push through to a desired end. Peacekeepers are soldiers as a matter of appearance more than function. A peacekeeper can shoot back if personally threatened, but only after exploring other measures, including remonstration, retreat, and warnings. Peacekeepers bear a close resemblance to civilian observers and relief workers who just happen to carry a sidearm with a bullet for the last exigency. The idea in classical peacekeeping, by the account of early adherents, is not to use armed force to advance an end, but rather to use moral witness, reportage, presence, and humanitarian assistance, even in a mission undertaken in the midst or aftermath of fighting. Peacekeepers will monitor a truce or separate former combatants, but will not repel one side if it breaks through the truce line.

Consent is the second classical condition. Peacekeepers are present by invitation, in a consensual deployment. If one party balks, the peacekeeper has to leave. Scruples about the justification for intervention-politics, transparency, and autonomy-are avoided because the monitor remains as a delegate of the parties. Consent is wholesome justification, and we needn't pursue rabbit trails on whether there are limits to a party's ability to bind its will, since the consent is continuous and revocable.

Neutrality is the third condition. This also goes to party autonomy, but with a very different set of moral problematics. The peacekeeper is required to be neutral between the parties to a conflict, to make no judgment on the merits of the underlying dispute. He is not to impose a political solution; indeed, if he tries, one of the sides would withdraw its consent. Peacekeepers are to carry out functions no one quarrels withobservation, civilian assistance, humanitarian aid.

The classical condition of impartiality has made many of us chary about the whole enterprise of peacekeeping in the current circumstances of Yugoslavia. Civil wars are one of the most morally unregulated activities of modern life. There is no theory of distributional justice in a civil war. It's pure tooth and fang. Pure Darwinianism. Whoever is stronger wins. There is no international standard that bars the use of force by a domestic party seeking to win a civil war. To have the United Nations deeply involved in the neighborhood, while the unregulated use of force proceeds between the parties, is uncomfortable for people who think of international order as morally laden.

The challenge made to multilateralism-for its politics, lack of transparency, and burden on autonomy-rationally explains the classical conditions of minimal force, consent, and impartiality. A limited presence, 
the milk balm of consent, and equidistance from the parties help skirt the question of how multilateral decisions should be justified, since little is being done. Whether all issues of legitimacy are successfully avoided is another matter, especially if one believes there are affirmative duties to act.

Our immediate subject today is the origins and current health of U.N. peacekeeping. Peacekeeping is often criticized by hard-headed realists, who don't have much time or money for humanitarian causes. Unsavored by these skeptics is a key historical fact: Peacekeeping is deeply connected to strategic conflict. Many early operations stemmed from the need to neutralize and quarantine quarrels with strategic potential. The early Cyprus operation is an example. The United States worried that its two NATO allies, Turkey and Greece, would grasp each other's throats over Cyprus. Especially after the coup of the Colonels, it was important to prevent intra-alliance violence, and peacekeeping was key. The Congo crisis, an early occasion for nation-building, saw the U.S. request, invite, even implore the United Nations to undertake the operation, lest the Soviets go in.

Many current operations stem from the devolution of strategic conflicts. Consider El Salvador, Mozambique, Angola, Cambodia. One of the reasons why, despite the rhetoric on Capitol Hill, the United States is so deeply interested in these missions is that they are the dénouement, the winding-down of old battles for influence in the Third World between strategic opponents. Peacekeeping is not pure humanitarianism. Peacekeeping has provided an important buffer between dangerous nuclear adversaries. India and Pakistan in the Kashmir Valley give another example. The purpose of dampening potential strategic conflict is why superpowers were long considered to be disqualified from acting as peacekeepers. The point of peacekeeping was to de-escalate conflicts that otherwise might pit East and West against each other, to keep the superpowers safely in their corners.

Three popular cultural images summon the evolution of peacekeeping in its new form. The first is the man who came to dinner. As soon as you invite him in, his shopping bag full of papers and cans, you know you will never get rid of him. This is what the military calls "mission creep." Peacekeeping has the added moral spin of the good Samaritan's special duties, falling upon those who become involved. The common law of torts says that you do not have to rescue somebody, but once you begin to rescue, you have special burdens. There is a moral difference between the stranger and a participant in a relationship of affect or reliance.

The second image is from our political history: Herbert Hoover and the Belgian relief of the post-World War I period. Hoover embarked on an extraordinary mission to rescue the European continent from starvation after World War I. The fighting had ended and the immediate problem was food delivery, but the continent was prostrate. The breathless daring of Hoover's reconstruction, later repeated in the Marshall Plan, is a key precedent for the ambitions of nation-building in peacekeeping. 
The third memory is the Vietnam War. Many of the tasks peacekeeping presents are not so different from the ambitions we had in Vietnampolitically remaking a society in a way we prefer. The most haunting document in peacekeeping is a small handbook published by the United Nations on behalf of two Russian authors which lauds the efficacy of Vietnamese counter-insurgency operations as a model for peacekeeping. The frustrations of Vietnam should allay our surprise when peacekeeping missions do not succeed in remaking a society on an emergency basis. At the same time, the success of some peacekeeping operations in demobilizing combatants, bringing insurgents into a process of negotiation, and catalyzing the change from civil war to politics, is a partial curative to the disillusionment of the Vietnam War.

Scale has changed from the classical period of peacekeeping. The number and size of operations has exploded over the last five or six years. Anything growing so fast will have management problems. The U.N. budget for peacekeeping multiplied in six years from 230 million to 3.6 billion U.S. dollars. The number of operations has increased from five to seventeen, and the number of soldiers on the ground from 10,000 to 70,000. Quick growth, in a difficult-to-manage multilateral organization, is likely to have some deformities, and not to be keenly structured.

The scope of our ambition has also changed. Peacekeeping now looks like a summary of all the hopes of the 1960's and 1970's for development aid and political transition-to somehow remake emerging countries as prosperous, democratic, and stable societies. The old classical mission of peacekeeping-interposing lightly armed troops to monitor a truce, to observe, perhaps to rebuff some small trans-border terrorist incidents-has been transformed. The menu now includes complicated postconflict tasks (cantoning and demobilizing combatants, supervising elections, establishing working judicial systems) and even more devilish tasks during war, such as delivering humanitarian aid, preventing genocide (as in the attempt by the French in southwestern Rwanda and what we hoped for in Bosnia), handling massive refugee flows, such as the million people crossing the border in a two-week period from Rwanda into Zaire, and figuring out how to sustain refugees during their exile. There is some hope of limiting war's destructive effects and lowering civilian casualties by discouraging violations of the law of armed conflict, jus in bello. These were formerly addressed only after the fact, once the conflict was over, by a war crimes prosecution, truth commission, or historical judgment. Now we suppose that even while the conflict is unfolding, we should be able to limit the abuse of war-fighting techniques, by garnering public opinion, imposing economic sanctions, or threatening retaliation. We have not succeeded by any measure in the former Yugoslavia, where the dreadful practice of ethnic cleansing continues, with such jus in bello violations as bombardment of residential areas in cities and the execution of civilians. But discouragement should be tempered by realizing that our ambitions have greatly expanded. 
We are also using Chapter 7 enforcement power for the first time in peacekeeping. In Somalia, and in elements of the Yugoslav operation, the Security Council authorized peacekeepers to operate even without the consent of the parties, under Chapter 7 enforcement authority. Even where consent is claimed, for classic Chapter $61 / 2$ peacekeeping, often it is constructive, even fictive: acquiescence rather than vocal agreement, consent by a de jure leader who lacks local control, or a de facto war lord who lacks any representative legitimacy.

Now to some of the current problems and controversies in peacekeeping. The first problem with peacekeeping is its uneasy resemblance to colonial guardianship. Some observers speak of "failed states"-a locution resented by the developing world, which points out that European state formation was a slow and difficult process. The "failed state" proposal calls for the United Nations to step in, perhaps through the Trusteeship Council, when local leaders are unable to stem anarchy or govern effectively. At times there is almost an intimation that sovereignty does not properly belong to people who cannot employ it well. What sounds so utterly benign as peacekeeping can devolve into a kind of multilateral condescension. While I don't believe in accepting human suffering as growing pains (the whole corpus of international human rights law argues against that), nonetheless, the need to respect autonomous political development remains, whether it is a multilateral or a unilateral intervention.

The second great debate is over the use of military power, with a postVietnam ennui about the efficacy of force. Sometimes, indeed, there isn't much achievable by the direct application of military force. To our frustration in Bosnia, for example, even where we know what type of territorial settlement we would like the Bosnian Serbs to accept (whether we say it aloud or not), air power in a mountainous region may not be adequate persuasion. Without thousands of ground troops to secure the area, a military solution may be unavailable. High technology, so efficacious in Desert Storm, doesn't serve half so well in the intricate terrains of civil wars, against unsophisticated combatants who are not subject to hierarchical command and control, who may not even see themselves as a single political unit. What the United States learned in Vietnam, others are beginning to learn too. At the same time, Americans have a peculiarly impatient account of military force. We are wedded to the Weinberger doctrine: Massive quick force. This was the theory of General Grant and General Eisenhower. We go to war rarely, but when we do, it's to be overwhelming and finished with lightning speed, a defensive blitzkrieg. The French and the British have a more imperial sense of using force around the edges, finessing, perduring, managing, enduring, temporizing. The American approach may be less suited to the task of policing civil war conflicts. This will be one of the great tests of Bosnia-to see whether the use of force American-style can help stem the fighting.

The United Nations faces another problem: it has reached the limits of its operational capacity. The Department of Peacekeeping Operations is staffed by wonderful people, overworked and dedicated. But at the 
same time, the organization was never set up to be a military command center. It has gained operational capacity very slowly. It finally has a 24 hour situation room. The United Nations still lacks real-time intelligence. It lacks satellite telephones to communicate straight to the field. For example, in the Rwanda emergency, Secretary-General Boutros-Ghali had no direct link to the head of the UNAMIR troops, interfering with assessment of the situation. The United Nations decisionmaking apparatus is diffuse. It's as if you tried to run a war through a faculty meeting-gaining consensus among very fractious people and then trying to get the dean to transmit the message accurately. The missing military infrastructure, the archaic qualities of the Secretariat, and the preeminence of members' inconsistent political wills, mean the United Nations does not have a sophisticated capacity to run military operations.

There is now the chastened sense, even within the Secretariat, that if an intervention involves enforcement, it must be contracted out to a willing country or coalition, a "coalition of the willing" who are militarily able. Even in more classical peacekeeping operations, the attempt to combine troops from middle-range powers and emerging countries oftentimes has not yielded good results. The troops are under-trained, lack equipment, may not follow ordinary discipline, and even violate the laws of armed conflict. Our ambitions for peacekeeping may have outstripped the available instruments.

There is a worry as well about contradictory aims for the United Nations. The organization's diverse aims may be incompatible. Jan Eliasson, who was Under-Secretary-General in charge of the Department of Humanitarian Affairs, worried aloud before he resigned that the humanitarian purposes of development aid and refugee assistance could be prejudiced by the attempt to get into enforcement operations. Even if aid agencies are based in Geneva and the security apparatus in New York, this subtle difference is lost to a person on the ground in Mogadishu. U.N. workers don't wear different emblems or different color hats. The acceptance of a humanitarian aid worker may be withdrawn in anger at a military operation. The U.N., some say, is at risk of losing its development and humanitarian soul, when its public face is martial.

The moniker of peacekeeping is also being stretched to serve as a polite cover for quite different political aims, multilateral and unilateral. For example, much of what the United States seeks to do in Europe today, in the enterprise of bolstering Eastern European friends against any resurgence of Russian power, is done under the heading of peacekeeping. We have been conducting civil defense exercises with former Warsaw Pact countries, including Poland and the Ukraine. A conciliatory label makes the joint exercises less objectionable or provocative to the former Soviet Union. The polite title of peacekeeping has been applied to Partnership for Peace exercises on humanitarian emergencies, nuclear emergencies, and environmental emergencies. We practice as well with the Russians, to remain even-handed. Nonetheless there are two militaries getting used to each other operationally, marrying up their command structures, getting 
to know each other's doctrine under the guise of peacekeeping. The Partnership for Peace has been a brilliant success. With great respect for George Kennan, one can call it "soft containment." It is good policy, and useful in the current political situation in Europe. But applying the name peacekeeping to these cooperative exercises, runs the risk of corrupting the meaning of peacekeeping. Peacekeeping is not containment.

On the Russian side, "peacekeeping" often looks rather like old Soviet hegemony. Take the counter-insurgency operations conducted in Tajikistan, Abkhazia, North Ossetia, and Ingushetia. You can call it peacekeeping. You can call it empire. Bill Odom of the Hudson Institute pointedly observes that it looks a lot like Grachev asserting the old sphere of influence of the Russian bear; calling it peacekeeping does not change its hegemonic dominance. In memory of Orwell, one should avoid the multiplicative use of the word "peacekeeping" as a palliative for everything that unilateral powers wish to undertake.

There is at the moment no sufficient theory of triage for intervention. One can pose standards in the abstract. The United Nations ought to intervene where there is a great loss of human life or limb, or where there is great danger to stability in the region, and intervention can be accomplished at reasonable cost to life and fortune. But one cannot always anticipate how crises will play out, and, to be effective, one must often intervene before the costs of inaction have become apparent. General Romeo Dallaire, the Canadian commander of UNAMIR, maintains he could have prevented the Rwanda slaughter if only he had a thousand good men and true in Kigali, at the right time. The mandate was not forthcoming.

In fact, the situations of intervention have been catch-as-catch-can, CNN, sentimental relationships, but not subject to any great theory of moral or political justification. We did Somalia. We didn't do Sudan. We didn't do Burundi or Rwanda for several times around. This absence of articulate theory may not be an urgent moral problem because the number of crises where we ought to intervene will dwarf our capacity. But theory might help us rank-order crises, and perform a political triage. The chafing by some U.N. members at Security Council action-that peacekeeping and humanitarian intervention not become a plaything of the permanent five members of the Security Council-is in part because we lack an adequate account of when to go in, and when not.

Finally, let me say a few words about the U.S. role in peacekeeping. This is a red-hot issue in Washington. To be sure, the Contract with America featured in the 1994 Congressional elections said nothing that demanded withdrawal from peacekeeping. The Contract called for adequate command and control of U.S. troops and protection of vital American security interests. One can make a strong argument that increased support for peacekeeping is the most faithful interpretation of the Contract with America, since peacekeeping helps to manage regional conflicts while spreading the cost. Nonetheless, House and Senate Republicans brought forth the proposal that the United States withdraw from any sig- 
nificant role in peacekeeping. The United States is the largest financial contributor to peacekeeping. We pay, in current assessments, $30.4 \%$ of peacekeeping costs, although we do not donate many troops.

What the Congressional Republicans have built upon is the anxious sense that the United States lacks a settled account of its own proper role in peacekeeping. U.S. troops face unusual difficulties as peacekeepers in most operations. An early disqualification was strategic-the whole point of peacekeeping was to neutralize conflicts and avoid involvement of the superpowers. A newer reason why we are disabled from peacekeeping is that the United States is too credible as a retaliatory force. If an insurgent is looking for attention, and takes a Nordic peacekeeper hostage, there is not much his country can do about it. But if an American is taken hostage, there is the expectation from the Iranian hostage crisis that we are going in with lasers and gunships. American peacekeepers become targets, and this can escalate rather than de-escalate the conflict. American war-fighting doctrine does not fit the traditional ethos of peacekeeping. On a recent panel for West Point cadets, there was a pitched battle between Colonel James Terry, legal counsel to the U.S. Joint Chiefs of Staff, and Colonel Toralv Nordbø, military advisor to the Norwegian mission at the United Nations. Colonel Terry talked about the Weinberger doctrine, and the need for overwhelming force. Colonel Nordbø uttered a cri de coeur, asking why there was a quantum theory of military force that disdained graduation. Exposing peacekeepers to possible harm, minimal use of force, an almost Quaker-like self-restraint, is foreign to the way we have been schooled to fight since Vietnam. Some military observers believe that you cannot adapt American fighting forces to peacekeeping without changing the military's whole character and set of reflexes. At the Fort Polk peacekeeping exercises in August 1994, mock negotiations were held between the two civil war combatants. The American commander came into the mediation meetings with his tin hat on and camouflage paint. It took the British observers awhile to explain that a combative demeanor was not always what you wanted to use in this kind of negotiation, which mixes civil and military concerns in a very complex brew.

So there is a sense that the post-Vietnam Weinberger doctrine makes the United States psychologically unsuited to engage in peacekeeping. The question is, what else are we to do? The United States is badly needed for some things: only our military has airlift adequate for transcontinental operations. We have better logistical support, and better real-time intelligence than anyone else. And then there is money. But it is difficult to conceive of limiting our role to supplying a supportive infrastructure. Our political leadership probably depends on some participation on the ground, since casualties are a sensitive issue for every country.

The United States could also help the United Nations plan and put together political coalitions. At the moment there are no templates for peacekeeping operations. They are invented with a blank piece of paper each time. There are no standard scenarios to be adjusted. There are no operational plans for which country can donate "packages" of military or 
humanitarian aid in varied geographic settings or crises. Very slowly the United Nations is getting an inventory of what, in theory, each country might be willing to earmark, but this is done without thinking through real and predictable political sensitivities. Mrs. Sadako Ogata, the High Commissioner for Refugees, is forced to dial for dollars each time she has an operation, begging for a water package or a sanitation package. The United States could be tremendously helpful in sophisticated planning. Desert Storm was brilliant in so many ways, especially in the planning of operations. The United States could also help with multilateral diplomacy, the art of soft arm and strong arm, to persuade countries to take part in operations. Instead, we have been mocking the United Nations for not equaling our multilateral diplomatic capacity without realizing that we are indeed the U.N.

In military doctrine we've done very little in trying to game what can be done with interpositional forces to prevent conflicts from spreadinghow to work early cantonment in a genocidal situation. The military services have yet to look at how reasonable force structures might prevent the escalation of civil wars.

These are some of the problems that remain. This is a wonderful and terrible time to talk about peacekeeping. The U.N. presence in Bosnia and throughout the former Yugoslavia remains problematic. In March 1995, Croatia threatened to withdraw its consent to the presence of U.N. peacekeepers, taunting the Security Council to deploy peacekeepers by Chapter 7 mandate rather than by Chapter $61 / 2$ consent. In Liberia, and in the former Yugoslavia, there still is a sense that conflicts have been prolonged by the presence of peacekeepers; humanitarian aid resupplies the combatants; having peacekeepers on the ground too easily serves as an excuse to fail to intervene in other ways.

Peacekeeping has a singular origin in a kind of ethical nonviolence. At the moment, its future is in jeopardy. We can celebrate many of its purposes, such as delivering food on the ground to Sarajevans. But peacekeeping operations have also bitten off more than we can chew. The faint-hearted ask that we walk away from the challenge. But the optimists assume we will keep plugging and, in the best American spirit, turn things around. 


\section{Questions and Answers Following the Morning Session}

Question: For Mr. Lee, are you outlining a new test for U.N. intervention? From the point of view of the U.N. bureaucracy, is there a power to say plainly that this is an operation we can't carry out?

ROY LEE: I think you have raised a very important question going to the heart of the problem. Mandates are created by the Security Council. The Secretary-General is requested to implement the mandates. Sometimes, because of divergent national interests, the mandates are not very clear or are impossible to implement. Nevertheless, from the process point of view and institutionally and constitutionally, the Secretary-General has to implement them. And there are a great many problems in the process of implementation. The Secretary-General does not have the power, really, to challenge when a decision has been made. He just has to do his best to implement them.

So I think this raised a very good, very basic question which Professor Wedgwood and Professor Tesón have mentioned: Can the Security Council do wrong? Look from the legal point of view. If a Council action is wrong, first, you don't have to vote for it; second, after a decision has been taken, you can ask procedurally to reconsider it; and thirdly, if the General Assembly does not agree with the decision or the mandate, the Assembly can ask for an advisory opinion from the International Court of Justice. So far, none of these measures has been resorted to. Why? It shows this is not really a legal question, but basically political. The legal means are available, but there is no will to resort to these. And consequently, whatever the Security Council decided, according to the procedure, becomes the law and has to be implemented. I think this raises a very basic question we need to consider.

RuTH WEDGwOOD: Can I add an outsider's comment, since I am not restrained by Secretariat politeness?

The bully pulpit that the Secretary-General ought to exercise, telling members plainly what he can do or can't, will be available only where a Secretary-General is committed to serving just one term. The current Secretary-General has twenty-three months to run on his first term, and says he is not yet ready to make up his mind about a second term, he'll see later, and will have to ask his wife. It is widely believed that SecretaryGeneral Boutros-Ghali would like to serve a second term, if his re-election is not opposed. But the problem faced by any Secretary-General is that you can't get elected if you displease one of the major powers. So that is one problem: a Secretary-General can't speak freely while running for office.

A second problem is univocality. Even though many of the specialized agencies run independently, the public sees them as part of a single institution. The public face of the U.N. has been the Secretary-General. These agencies do not vocalize to a broader political public their own judgment whether it is possible to participate effectively in the security 28 CORNELl INT'L L.J. 641 (1995) 
missions designed by the Security Council, indeed, whether their own programs might be jeopardized by a particular peacekeeping or peace enforcement operation, per Jan Eliasson's complaint.

QUESTION: What is the evolution of international law on sovereignty?

Fernando Teson: I don't know the answer to the complete question of where the evolution is going toward. I can tell you what I think part of the problem is. If you believe that statehood and sovereignty are ends in themselves-so that, for example, it is a very bad thing that sovereignty is collapsing somewhere-then of course you will be concerned about a number of things. You will want to preserve the sovereignty of the unity or entity that is collapsing, failing. You will be nervous about intervening for many of the reasons that Ruth said: you want to care about people, about their autonomy, even if it is failing.

On the other hand, if you introduce some idea that sovereignty is not a self-sustaining concept, but rather serves other ethical goals, then a sensible approach would combine some of the concerns that Ruth mentioned, allowing people to guide their own destinies, with an awareness that we are talking about "failed" states or problematic societies. The structures may not be serving the people, the moral goals or the ethical goals or the legitimate goals that sovereignty should help. Therefore I think the United Nations should be more willing to do some of the things Ruth mentioned-going in and helping refashion the local institutions so they respond to the needs of the people in a legitimate way and a realistic way.

RUTH WEDGWOOD: Peacekeeping also comes from the growth of international human rights law-going behind the de jure government to look at the rights and claims of the people, including minority nationalities. One of the great successes of peacekeeping operations has been a formal beginning to democracy-the conduct of complicated elections in Cambodia and El Salvador and Mozambique, with people going to the ballot box for the first time. I do worry, from a more sinister view, that there are many ways people will express consent and resistance, and the formal act of casting a ballot is only one of them. Fighting to the death is another. In realpolitik, where we want to achieve an outcome that is reasonably stable over time and that reflects people's true preferences, electoral formalism may not be sufficient. One hates to give place to standing armies and people with bigger bodies. But intensity of preference is deeply registered in civil wars. For "failed states," as we discovered in Somalia, the possible superficiality of formal democratic procedures is going to be a continuing problem.

ROY LEE: One of the basic problems of international law and international relations at the moment is that they promote the interest of states; the whole system is state-based, and the U.N. represents these national interests. Other interests are not channeled and are not focused. The primary purpose of representation in international bodies is to promote state interests. So if we really want to find a solution, we need to see what else have 
we got. Maybe that is precisely the problem. The U.N. reflects the interest of governments.

DAvid WIPPMAN: Is consent a legitimate basis for coercive intervention when there is no effective government? How do you determine the appropriate parties from which to seek consent?

RoY LeE: So far as Somalia is concerned, I would like to invite you to go back to the history and remember the Secretary-General first wrote a report on the situation in Somalia. One of the points he mentioned is that in Somalia there was large-scale starvation, there was no government and the country badly needed assistance from outside. Therefore he recommended a peacekeeping operation. And then later on, the Security Council decided that force should be applied. So in that case, it was not based on consent. When it authorized force, the decision was based on Chapter 7. Somalia was quite different from other operations which were based on consent.

David Wippman: But in Somalia, at least at the outset, the U.N. solicited the consent of the principal warring factions, and only later turned it into a Chapter 7 operation.

ROY LEE: That is correct. Essentially you have to negotiate with somebody in power.

RUTH WEDGWOOD: I took your question to be a Fernando footnote. Is the U.N. misguided in seeking the consent of local warlords? If consent comes from tribal leaders who have local cultural legitimacy, fine. But who cares what an unelected thug agrees to. Consent can serve the purpose of minimizing violence. In a non-democratic situation, leaders' consent may otherwise lack any deep connection to political legitimacy. 
HeinOnline -- 28 Cornell Int'l L.J. 6441995 